\title{
The use of rhetorical devices in the writings of Arab high school students
}

\author{
Adel Fouzi Shakour \\ Department of Hebrew Language and Literature, Al-Qasemi - Academic College of Education, P.O.B 124, 30100 Baqa El-Garbia \\ Email address: \\ adsh2007@gmail.com \\ To cite this article: \\ Adel Fozi Shakour. The Use of Rhetorical Devices in the Writings of Arab High School Students. International Journal of Language and \\ Linguistics. Vol. 2, No. 6, 2014, pp. 403-414. doi: 10.11648/j.ijl1.20140206.20
}

\begin{abstract}
The article analyzed the rhetorical devices used by Arab high school students when writing in Arabic. Professor Rachel Landau's book The Rhetoric of Parliamentary Speeches in Israel, Tel Aviv, Eked, 1988 provided the reference for the analysis. Landau applied Western rhetorical criteria and concepts to the analysis of Israeli political rhetorical style. We can justifiably also apply Western standards to Arabic rhetoric since rhetorical style is an independent literary genre beyond the linguistic structure of any language, and as such is supranational. Landau adopts the stylistic-rhetorical approach to the study of rhetoric, which includes rhetorical registers that generally operate on the emotions and rhetorical argumentation, which includes registers that generally address the reason.
\end{abstract}

Keywords: Rhetorical Devices, Arab Students, High School, Writing in Arabic

\section{Introduction}

Rhetoric is the art of persuasion as opposed to a simple communication of information. The aim of rhetoric is not to spread truth and present it plainly and openly but to convince an audience to accept a speaker's position - one which not necessarily congruent with that of the audience. The arguments alone cannot persuade, but when presented in a certain way, they become acceptable to the audience1.

Language is a device that enables us to understand the world. Speech is the expression of understanding (Sophia) which lets us explain situations, construct dialogue, and clarify and investigate the world. The word is the most powerful expression of human ability; without it human beings would have accomplished no more than animals intellectually2. Communication is the essential activity that links the various parts of society together and allows them to function as $n$ integrated whole. 3 Rhetoricians understand the importance and power of words. They use strategies that rely on words, which they see as a tool to be use to effect, often in sophisticated ways. They seek to fashion a new reality, which the audience can accept as genuine. Rhetoricians generally do this by eliciting a sense of agreement with the listener and

1 Gitay, 2011, p. 55; Tsur, 2004, p. 64; Carpenter \& Thompson, 1999, p. 7.

2 Searle, 2002, p. 18; Gitay, 2010, p. 27.

3 Mio, 1997, p. 113; Graber, 1993, p. 305. once that feeling of understanding has been established, the task of persuasion can begin. 4

This article analyzes the rhetorical devices which were used by Arab high school students from a high school in northern Israel when writing in Arabic. The students were asked to write a letter to the Israeli Interior Minister and persuade him to allocate more resources for developing Arab villages. It was hypothesized that the students' writing would use the stylistic category of rhetorical devices and the argumentative category of rhetorical devices, and sometimes both.5

210 students in six classes were assigned a writing exercise in Arabic. The first step was to obtain an impressionistic assessment of the students' writing. A preliminary reading revealed that the students' writings included various rhetorical features: rhetorical devices using syntax, semantics, and discourse analysis. When a rhetorical device was identified in one student's writing, it was also sought in the other students' writing and its frequency of use determined. Finally, a profile was created of the rhetorical

4 Gitay, 2013 (b), p. 120.

5 Landau (1988, p. 17) used the term "שידול" for "persuasion" a term she used to denote arguments that address the emotions. This contrasts with "שכנוע" which refers to "conviction" and refers to arguments that address the intellect. 
features used in the students' writing: in other words, the rhetorical and stylistic devices and argumentation that they used.

\section{Stylistic Rhetoric}

A common analytical approach when studying rhetoric is to examine the wording of persuasive messages and the tools of persuasion that speakers and writers use. Influential figures who express their ideas publicly use a variety of argumentation approaches and methods to appeal to their audience's logic and emotions. Stylistic rhetoric targets the emotions and is known as rhetorical appeal. 6 When appealing to the emotions, speakers' use specific elements and structures in their messages in order to arouse given responses in their audience, such as sympathy, empathy, hesitancy, or rejection7.

According to Perelman and Olbrechts-Tyteca, "persuasive arguments" are arguments which claim things that are only valid for a particular audience. "Convincing arguments" on the other hand are arguments that seek the agreement of all rational people. In other word, a "persuasive arguments" is an argument which takes the viewpoint, beliefs, and needs of a particular audience into account. 8 This might include addressing a particular audience's emotions, which might not be effective if addressed to a universal audience that does not share those particular beliefs or needs. The goal of a speech which is addressed to a universal audience of listeners is to persuade while the goal of a speech which is addressed to a specific audience is to convince. 9

\subsection{Repetition of Syntactic Elements}

Darshan 10 cites Koch's study 11, showing that Arab political discourse very typically uses rhetorical repetition. This involves rhythmic repetition of phonemes, morphemes, roots, words, phrases and key sentences, sentence paraphrases, the multiple use of syntactic parallels between sentences, structures, and members. Repetition is the key to textual coherence and understanding the whole meaning of a text, which is a feature of discourse. 12

The force of rhetorical repetition is achieved in several ways:

A. Repeated phrases, anaphora, epiphora, repeated members and repeated syntactic patterns create a rhythm, a particular cadence. Word repetition creates a rhythmic musical effect which is produced by both the sounds being repeated and the repetition itself 13 . Repeating a message elicits aesthetic musical pleasure in the listener that helps to embed the message in the listener's mind, arouse the listener,

6 Tsur, 2004, p. 78

7 Tsur, 2011, pp. 74-75

8 Perelman \& Olbrechts-Tyteca, 1969, p. 28

9 Perelman, 1994, p. 20.

10 Darshan, 2000, p. 7.

11 Koch, 1983, pp. 47-52; Koch, 1981, pp. 179-180.

12 Tsur, 2004, p. 89-90

13 Landau, 1988, p. 63 and create an emotional tendency to agree with the speaker almost instinctively 14. Perelman argued that in order to produce the presence of the message, it is effective to stress undeniable fundaments at length: Increasing a person focus on them reinforces their presence in the listener's mind. Simply dwelling on a certain subject produces the desired emotion 15 .

In psychology, an emotional connection between a listener and an idea is called identification: A person identifies with real and symbolic objects which give rise to excitement, normally on an unconscious level. As a rhetorical device, repetition helps to instill the speaker's ideas in the audience's mind and to use the audience's involuntarily emotional tendency to agree with the speaker without considering the content16.

B. The parallel repetition of sentences is what produces the rhythm of a rhetorical text. That rhythm, which created by the rhetorical musical emphasis, helps in highlighting key ideas, and assists their recall. The parallelism within the rhythmic syntactic pattern creates a parallelism of ideas in the complementary

Members of the sentence which can either reinforce or oppose an idea, or divide a long idea being developed slowly, into smaller parts.

C. Besides creating a rhythm, syntactic structure can also break a rhythm by interrupting the symmetry in the length and structure of the parallel sentences / clauses on the first connection level. This happens when one part of a sentence on the first level contains other sentence parts which are repeated on the second connection level. A strong break happens in the beginning or middle of the sentence. When it is at the end, it is regarded as part of the rhythm which is generating the rhetorical force17. The connection-within-aconnection structure that breaks the rhythm and symmetry serves to focus the listener's attention on the idea. This break in the rhythm focuses the listener's mental energy on the idea that the speaker wishes to highlight; again, in order to persuade the audience 18 .

D. Repeating a lexical element, word, or expression in nearby or more distant sentences enables the speaker to establish continuity between the sentences in the speech and to connect them and give them cohesion.

E. Repetition using synonyms-repeating an argument multiple times with linguistic variations helps the speaker to impress the audience 19.

F. Sentence repetition-this allows the speaker to buy time to continue his speech. When speakers use stylized repetition they are not seeking to prove what they are saying and convince their audience that it is the truth by using logical proof: they wish rather to communicate a message which is not open to discussion by using repetition-as if that itself

\footnotetext{
14 Darshan, 2000, p. 7.

15 Perelman, 1994, p. 35.

16 Landau, 1988, p. 64.

17 Landau, 1989, pp. 116-117.

18 Landau, 1988, p. 57, 64.

19 Patai, 1973. pp. 53-55.
} 
were proof.

\subsubsection{Sentence Parts which Convey the Same Meaning by Using Synonymous Words / Expressions or Words from the Same Semantic Field}

Landau discussed the semantic relationships within expression, for example: synonyms, antonyms, and same semantic domain. She stressed that symmetrical repetition, involving not only structural and verbal repetition, is also a persuasion device, since we know that repeating an idea often can slowly break down opposition or at least gain the agreement of listeners with no definitive view on a matter 20 . Words possessing a high semantic load can also help to communicate a message since the text's inherent emotional force contributes to conveying the idea21:

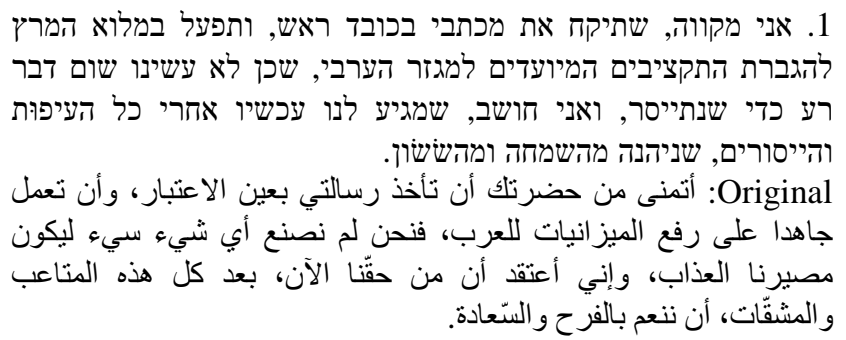

'I hope you will take my letter seriously and take active steps to increase the Arab sector budget, since we have done nothing to deserve this suffering and I think that after all the weariness and suffering, we now deserve some joy and happiness'.

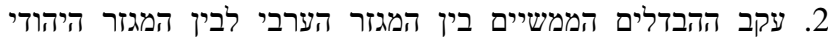

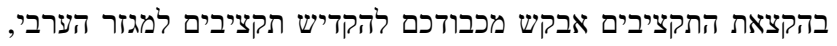

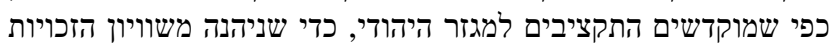

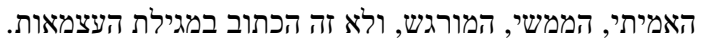
تونئ Original

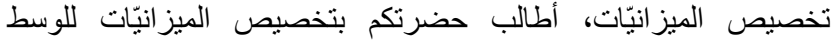

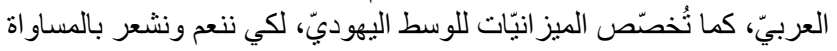

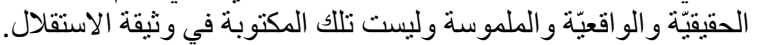

'In light of the substantial differences between the Arab sector and the Jewish sector in terms of funds, I respectfully ask you to give the Arab sector exactly the same funds as the Jewish sector and give us actual, substantial, perceptible equal rights not the ones written in the Israeli Declaration of Independence'.

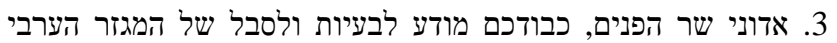

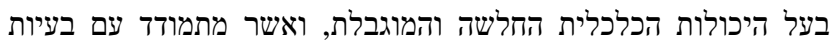

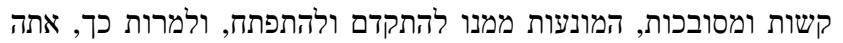
וממשלתך לא טורחים להקל עות עליו, להפך אתם לתות גורמים למצח להחות להמיר

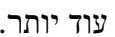

Original

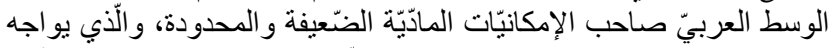

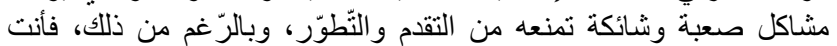

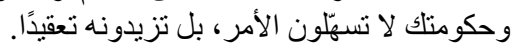

20 Landau, 1989, p. 117.

21 Livnat, 2001, p. 139.
'Dear Interior Minister, Your honor realizes the problems and suffering of the Arab sector as a result of its weak and limited economic abilities and its serious and complicated problems that prevent its progress and development. At the same time, you and your government take no trouble to improve matters. The opposite is true, you make things worse'.

\subsubsection{Syntactic Parallelism between Clauses Involving Repetition of Syntactic Patterns and Verbal Repetition}

$$
\begin{aligned}
& \text { 4. לכבוד, שר הפנים המכובד, }
\end{aligned}
$$

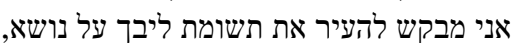

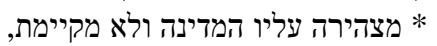

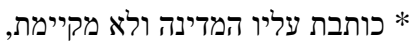

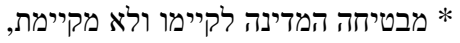

$$
\begin{aligned}
& \text { שוויון הזכויות. }
\end{aligned}
$$

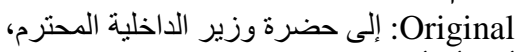

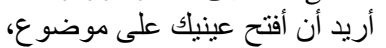

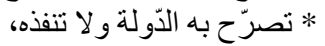

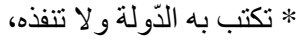

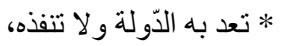

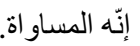

'Dear Interior Minister,

May I draw your attention to a subject which

* the state makes declarations about but fails to uphold

* the state writes about and fails to honor

* the state promises to provide and breaks its promise,

Equal Rights'.

A parallel syntactical structure made up of attributive clauses composed of: a present tense verb + repetition of the

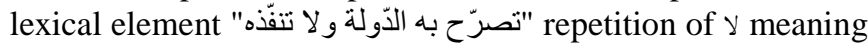
'not' + the subject + a prepositional phrase. The verbs and "تعِد " stress that there is no truth behind the state's declarations and promises. The writer keeps the punch line to last and breaks the rhythm in the last phrase " إنّه "المساواة". This delay in the message delivery increases the reader's curiosity.

\subsection{Figures of Speech}

Among the textual ornaments which have received a respected place in literary writing we find the various types of figures of speech. They include similes, metaphors, personification, allusion, metonymy, etc. What they share is a semantic shift from one area to another based on similarity between analogous things. 22

\subsubsection{Metaphor}

For at least 3 decades, researchers and political theorists have been interested in how metaphors are used as persuasive devices. 23 The metaphor is the most recognized figure of speech. It is a linguistic device that is used to transfer meaning from one sphere to another 24 . It is a semantic

22 Weinberg, 2006, P.52.

23 Mio, 1997, p. 114.

24 Landau, 1966, pp. 307-308; Lakoff, 2002, p. 63. 
deviation from the original meaning of a word, any word, taken from any part of speech. For example, the word "gap" in the phrase "he has a gap in his education" means "a lack" metaphorically.

In contrast to their traditional linguist counterparts, cognitive linguists see metaphors not as rhetorical embellishment but as part of human thinking 25 . Metaphorical expressions are seen as expressions that nourish our world view and form our thinking, and thus our actions themselves 26 . These are metaphors that grasp concepts in one sphere via another sphere: a sphere that borrows, and is the goal, uses a different sphere that lends, and is the source. Thus, for example, the identification "Time is money" allows us to relate to time metaphorically in terms of money: e.g., 'waste of time', 'investment of time', 'valuable time':

5. מדינת ישראל מתיימרת להיות דמוקרטית, ומנסה לצבוע את שוויון

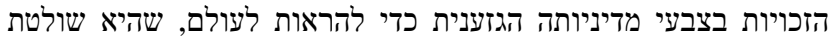

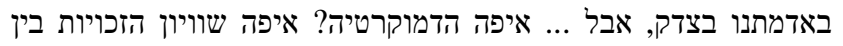
כפרינו הערביים לבין הערים היהודיות הציות? الو Original

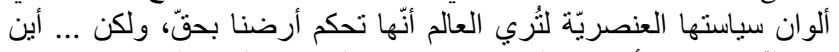

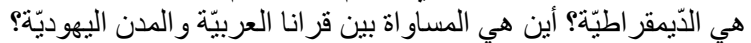

Through the colors of its policy, the state of Israel proclaims democracy and attempts to dye the equality of rights in the colors of its discriminative policy, to show the world, that it justifiably controls our land, but ... where is the democracy? Where is the equality of rights between our Arab villages and the Jewish towns?'.

- A metaphor for a fake and untrue equality of rights. This expression nourishes the paradox that exists between the declarations of the State of Israel regarding equality of rights, and its discriminating policy against arab citizens.

- As a metaphor to the double standars that characterize the policy of the state of Israel. The word "color" emphasizes the diversity and lack of homogeneity in its policy.

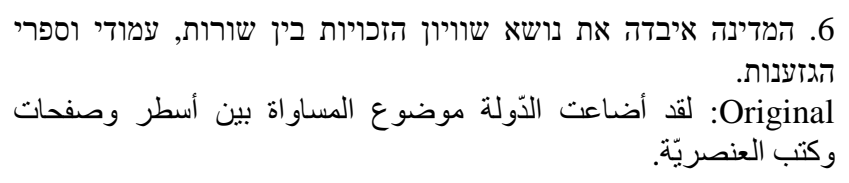

'The country has misplaced the issue of equality between the lines, pages and books of discrimination'.

- A metaphor that shows the discriminating policy of the state of Israel against its Arab population.

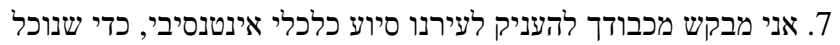

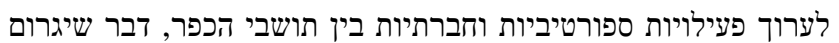

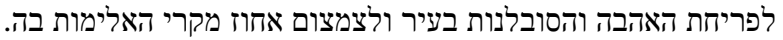
Original

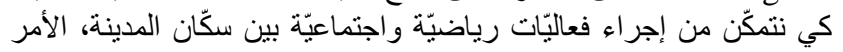

25 Abadi, 1988, pp. 47-56; Richards, 1965, p. 89-138; Abdul latif, 2012, pp. 117118; Gitay, 2010, 74-75.

26 Lakoff \& Johnson, 1980, pp. 3-6; Carpenter \& Thompson, 1999, p. 83.
فيّاً: الّي سيؤدي إلى ازدهار المحبّة والتّسامح في المدينة، وتقليل نسبة العنف

'I ask your honor to give our city serious financial aid, so we can establish athletic and social activities between the citizens, something which will lead to the flourishing of love and kindness in the city, and decreasing the percentage of violence in it'.

- A metaphor for the strong positive impact the financial aid has on the citizens of the town.

\subsubsection{Simile}

Similes are based on analogy. According to logicians, an analogy is basically a comparison portraying one or more similarities between one or more things27. Perelman noted that analogies help to explain the object of a comparison using the basis for comparison, where the basis for comparison has to be better known and more familiar to the reader than the object, because then it can explain the lesser familiar object. To do this, the two things must be from heterogeneous spheres so that they can mutually affect each other and further underscore their shared similarity 28.

With similes, this reciprocity is used to illustrate a quality / appearance / action of the object of comparison by providing a vivid picture. Rhetorically speaking, the simile transfers an explicit or implied quality usually from the basis of comparison to the object of comparison. It is generally a subjective-emotional quality, which seeks to influence an audience's feelings29:

8. דרישתנו לשוויון זכויות אינה סתם דרישה, ואנו רואים את הפער

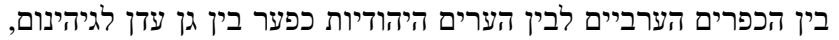
על כן פעל על צמצום פער זהת העים העים Original

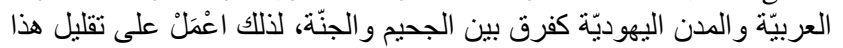

'Our request for equal rights is no ordinary request because we perceive the difference between Arab villages and Jewish towns as the difference between heaven and hell. Therefore do something to narrow the gap'.

Comparing the difference between the Arab villages and Jewish towns to the difference between heaven and hell stresses the disregard for justice, strengthens the message, and presses the reader to accept the writer's words. This is because the words "heaven" and "hell" have a powerful semantic load that contributes to communicating the message.

$$
\begin{aligned}
& \text { 9. מדינת ישראל לא מתייחסת לערבי כבן אדם, אלא כבובה, ששולטת }
\end{aligned}
$$

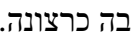

$$
\begin{aligned}
& \text { (Original } \\
& \text { كما تريد. }
\end{aligned}
$$

'Israel does not view the Arab as a human being, but as a puppet to control as it please'.

Comparing the Arab to a puppet emphasizes the

27 Weddle, 1978, p. 138; Tsur, 2004, p. 83.

28 Perelman, 1994, p. 91.

29 Landau, 1988, p. 89. 
discriminatory treatment of the state towards the Arab population, and their constant oppression.

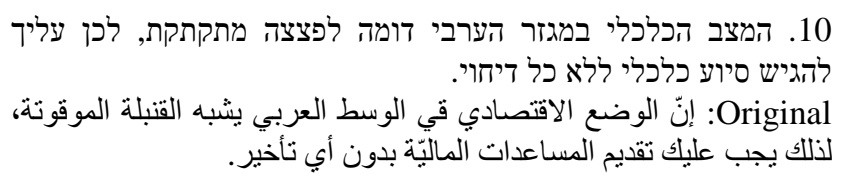

'The economic situation in the Arab sector is like a ticking bomb so you must provide economic aid without delay'.

The aim of the comparison is to reflect the immediate need for financial aid for the Arab population in the state of Israel'.

\subsubsection{Personification}

Personification is an artistic device which portrays inanimate objects, plants, or animals as human. In other words it ascribes human qualities to non-human things:

11. כשאנו מסתובבים ברחובות של הכפרים הערביים, נבחין ברחובות

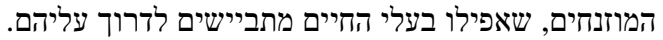

والّي :Original

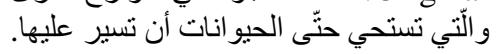

'When we walk down the streets of Arab villages we see streets that are so run down that even animals are embarrassed to tread on them'.

Personification here highlights the terrible condition of the Arab sector infrastructure.

12. האם אתה יודע, אדוני השר, שהמסים הולכים ומתרבים חודש

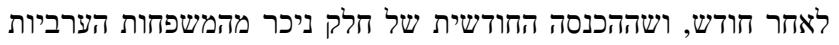

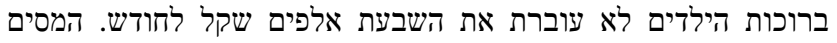

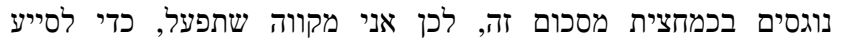
למשפחות הערביות העניות. وان Original

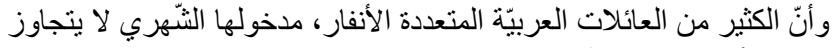

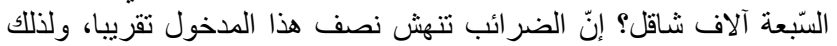

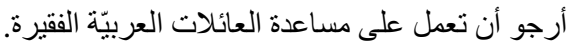

'Are you aware, Mister Minister, that taxes increase one month after the other, and many of the big arab families have an income that does not exceed the amount of seven thousand NIS. Taxes eat through approximately half of that income, therefore I hope you work on helping the poor arab families'.

The aim of the personification is to show the disparity between the outrageous taxes and the modest incomes of a considerable part of the big Arab families.

\subsubsection{Hyperbole}

Hyperbole is a figurative description that uses exaggeration to stress a point and impress it strongly on the audience. The Bible and medieval poetry often use hyperbole:

13. כל העולם מסתכל על מדינת ישראל כמדינה דמוקרטית, ולמרות

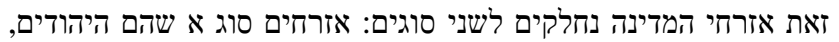

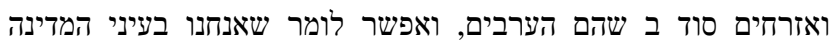
אפילו אזרחים סוג ג. Original

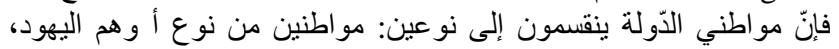

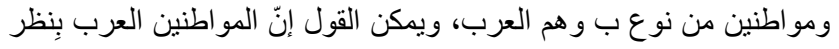

$$
\text { الدّولة مو اطنون من نوع ج. }
$$

The entire world views Israel as a democratic state; however, its citizens are divided into two categories: rank 1, which includes the Jews, and rank 2 which is the Arabs, and you can even say that the Arab citizens are close to being a Rank 3 in the eyes of the state'.

The exaggeration that describes the Arabs in the state of Israel as a rank 3 citizens emphasizes the inconceivable difference between the rights granted for Jewish Israelis as opposed to those given to the Arabs.

\section{Argumentative Rhetoric}

Argumentative rhetoric applies logical argumentative devices and is known as persuasive rhetoric. Rhetoric of this sort generally targets audience reason. When presenting a reasoned argument, speakers seek to establish a basis for their views or defend an action.30

\subsection{Analogical Argument}

Basic analogies create a similarity between two things based on a shared quality. An argumentative analogy or analogical argument goes a step further: if there are one or more similarities between two or more things $(a, b$,$) and a$ has an additional quality, it can be deduced by analogy that $b$ has the same additional quality 31 . There is no proof of the validity of this argument. The argument's conclusion is not necessarily a the outcome of the premise; that is the conclusion is neither valid nor invalid, but more or less probable32.

In this article, I do not discuss circumstantial arguments, namely arguments of the type "a is the reason for b". Circumstantial arguments have no logical consequentiality but rather a circumstantial link between cause and effect:33

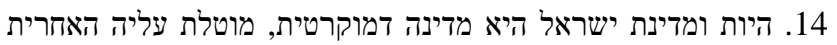

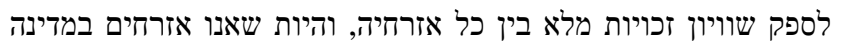

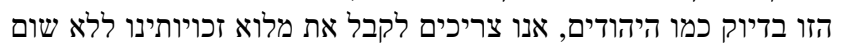

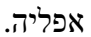
Original

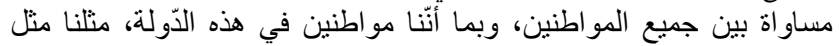
اليهود تمامًا، يجب أن نحصل الهوان على كامل حقوقنا بدون أي تمييز.

'Since Israel is a democratic state, and there has to be equality between all its citizens, and since we ARE citizens in this country, the same as the Jews, we need to receive our full rights without any discrimination'.

The Arabs and the Jews are both citizens in the democratic state of Israel. If the Jews get full rights, then the Arabs need to receive full rights as well.

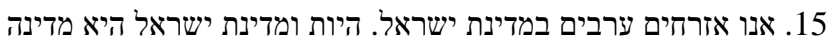
דמוקרטית, אנו צריכים לקבל את מלוא הזכוים ישריות שלנות בזינת ישריות כמיאמדינה כמות

30 Tsur, 2011, p. 74.

31 Copi \& Cohen, 1998, pp. 470-471; Darshan, 2000, p. 73; Tsur, 2004, p. 84.

32 Copi \& Cohen, 1998, pp. 470-471.

33 Israel, 2011, Part 1, 39-42. 
היהודים. - - - - - -

دولة Original

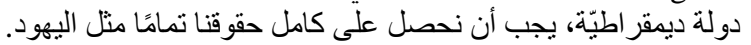

'We are Arab citizens of Israel. Since Israel is a democracy we must receive our full rights just like the Jews'.

16. מדינת ישראל קוראת לדמוקרטיה ולשוויון זכויות בין כל אזרחיה

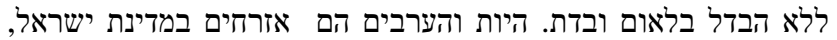

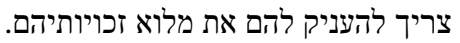
Original

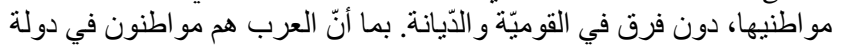
إسر ائيل، يجب أن يحصلو أنى على كامل حقو قهر.

'Israel calls for democracy and equal rights for all its citizens regardless of race or religion. Since Arabs are Israeli citizens they must granted their full rights'.

17. אני פונה אליכם בבקשה לסייע כלכלית בהקמת בית חולים בעיר

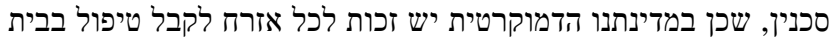

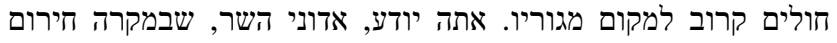

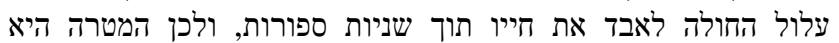

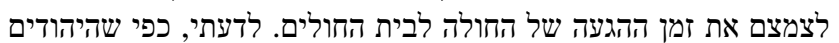

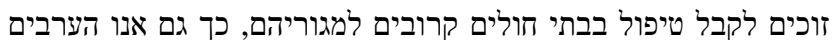
מגיע לנו אותה זכות.

Original

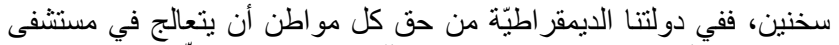

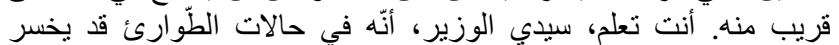

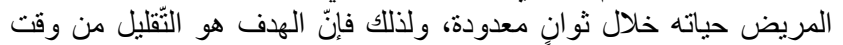

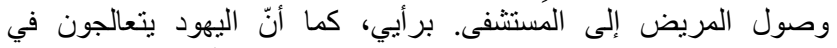

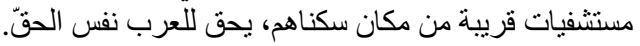

'I am turning to you asking for financial aid to build a hospital in the city of Sakhnin, because in our democratic state, each citizen has the right to receive medical treatment in a hospital close to where they live. You know, Mr. Minister, that in emergencies a person might lose his life within seconds; therefore the aim would be to decrease the time it takes for the patient to reach the hospital. In my opinion, and in the same way Jewish citizens have hospitals close to where they live, Arabs deserve the same right'.

Given that the Jews get to receive medical treatment in hospitals close to their living locations, Arabs, who are citizens of the democratic state of Israel, should enjoy the same privilege.

18. כפי שידוע, מדינת ישראל היא מדינה דמוקרטית, וזה אומר שצריך

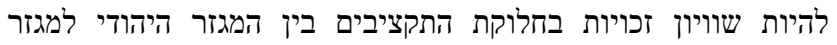

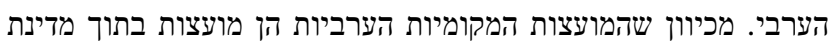
ישראל הדמוקרטית, הן צוון צריכות לקבל המותיות תקציביות הותים שווים לתקציבי בתוך המועצות המקומיות היהודיות. המות. أنها Original

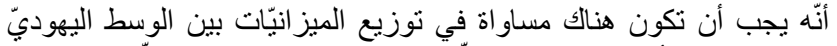

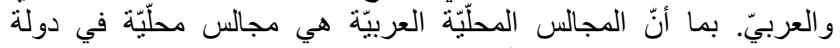

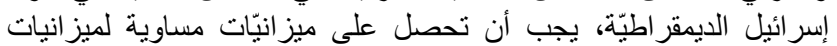
المجالس المحليّّة اليهوديّة.

'As we know, Israel is a democracy which means that there should be equal rights in dividing the funds between the
Jewish and Arab sectors. Since the local Arab councils are Israeli councils they should receive equal funding to Jewish councils'.

Jewish and Arab councils are local councils in the democratic state of Israel and should therefore enjoy equal funding.

\subsection{Rhetorical Questions}

Among other things, a speaker's arguments in political ideological discourse are based on patterns of indirect speech and rhetorical questions, which are part of a textual tapestry and an intentionally woven argumentative fabric. The rhetorical question is one of the most important aspects of argumentative rhetoric. It is an indirect speech act that seeks to express a emphatic assertion, with no expectation of a reply in most cases. 34

Landau discussed rhetorical questions at length highlighting three central types of rhetorical question 35 : "Yes-No" questions that open with the question " Have / Has?" etc., for example: the questions "Could it be that...?" "Is it true that...?". Positive rhetorical questions like this express strong negative assertions while negative rhetorical questions express strong positive assertions36, for example, Could it be that they actually have the right to speak for this country's residents? Rhetorical questions that start with a completion question word, such as "What"? "How"? "Why"? etc., apart from the question word "Have / Has"? for example: Which country besides Israel has compromised so much? and choice questions that are basically assertions which reject the first option and strongly approve the second option. For example: Could it be that you are genuinely worried about citizens' welfare, homes, and children, or do you just want their money perhaps in order to control and go on controlling and eat your fill at our expense?

Landau suggested that of the three types of rhetorical questions, rhetorical choice questions provide the most emphasis. She discussed at length the impact of including these questions in the text-rhetorical questions at the end of a sequence of declarative sentences, a series of rhetorical questions on one subject, putting a rhetorical question in a complex sentence, and splitting rhetorical questions.37

Livnat38 discussed Fruchtman's basic distinction between emotive and presentational texts 39. According to this distinction, persuasive texts are also emotional and their emotional character helps to convey their concealed message of persuasion. The writer uses the implicit information to convey his or her attitude toward the events and to try to influence the reader's views. Livnat identified several linguistic stratagems that expose the implicit information encoded in the text and divided them into four categories: syntactic stratagems, poetic stratagems, semantic stratagems,

34 Shaked, 2009, p. 139; Tsur, 2004, p. 83.

35 Landau, 1988, pp. 68-72.

36 Quirk \& Greenbaum, 1989, p. 200.

37 Landau, 1988, p. 209.

38 Livnat, 2001, p. 134.

39 Fruchtman, 1990, pp. 17-19. 
and stratagems linked to logical structures. According to Livnat, a rhetorical question is a linguistic stratagem that is linked to logical structures and aimed at increasing the text's emotiveness and directing the emotions produced in the reader in the particular direction the writer wishes:

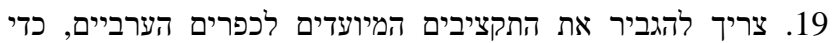

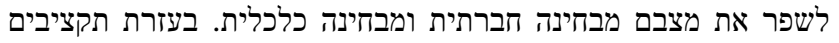

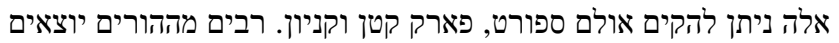
לערים היהודיות כדי לבלות. אולם ספורט, פארק קטוע אין בכפרים הערבים מהורים יוצאים דברים כאלה? לערים من Original

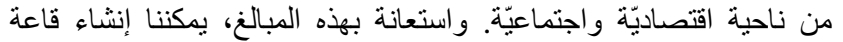

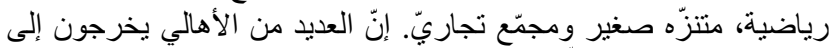

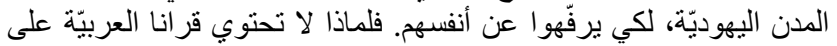

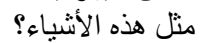

'The funding for the Arab villages must be increased in order to improve their socio-economic status. With the help of these funds it would be possible to build a sports hall, a small park, and a mall. Many parents go to the Jewish cities for leisure and entertainment. So why don't the Arab villages have such things?'.

20. אני מבקש מכבודך להקדיש יותר תקציבים לכפרים ולערים

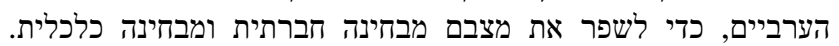

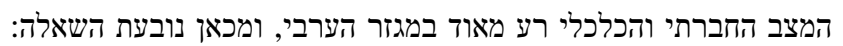

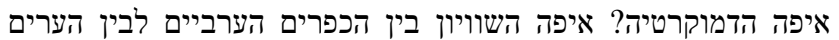

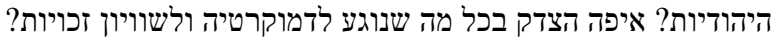
من Original

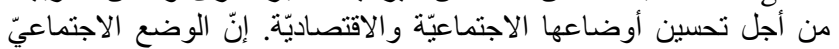

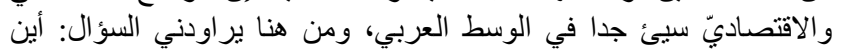

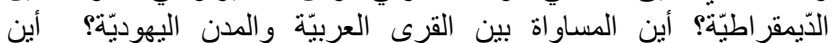
المصداقيّة في الديمقر اطيّة و المساو الئ الئن

'I ask your honor to increase the funding to the Arab towns and villages in order to improve their socio-economic situation. The socio-economic situation in the Arab sector is very poor which raises the question: Where is democracy? Where is the equality between Arab villages and Jewish towns? Where is the justice associated with democracy and equal rights?'.

21. רבים מההורים יוצאים לערים היהודיות, כדי לשעשע את ילדיהם

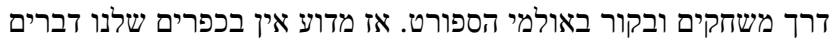

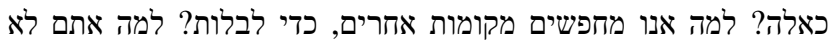

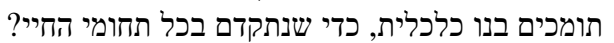
:Original

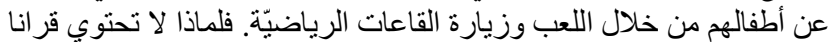

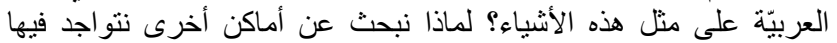

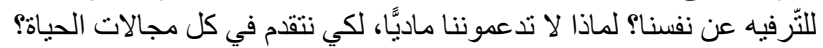

'Many parents go to Jewish cities in order to entertain their children through games and using sports facilities. So why don't Arab villages have these things? Why must we go to other places for recreation and entertainment? Why don't you support us

22. קודם כל אני מבקש לדבר על הגנים הציבוריים בכפרים ובערים

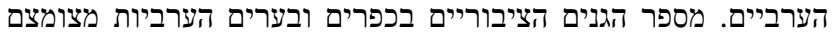

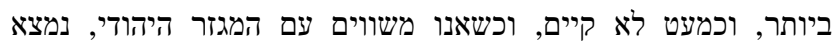

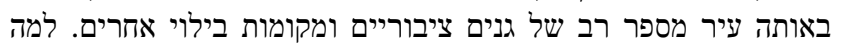

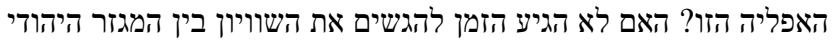

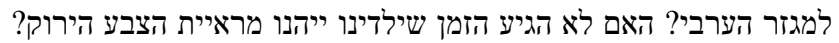

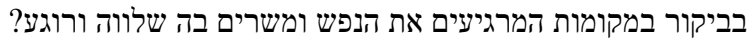
العرئ Original

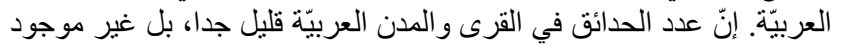

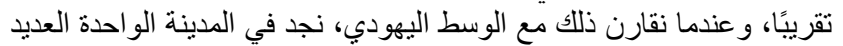

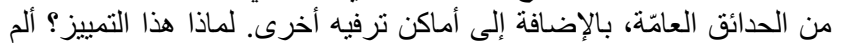

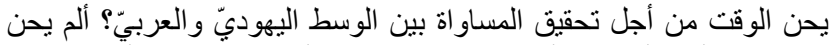

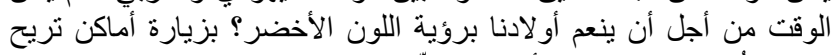

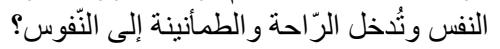

'First, I want to talk about the public parks in Arab towns and villages. There are very few-in fact hardly any-parks in Arab towns and villages and this contrasts with the Jewish cities where there are lots of parks and other recreation areas. Why does this discrimination exist? Isn't it time for equality between Jews and Arabs? Isn't it time our children enjoyed the sight of greenery and had play areas and places to go which relax the mind and create a sense of tranquility and relaxation?'.

The writer concludes the discourse unit with a volley of rhetorical questions, stressing the urgent need for JewishArab equality. The split rhetorical question that concludes the discourse unit also helps to strengthen the message.

23. בזמן טיולנו בכפרים ובערים הערביים של מדינות ישראל ניתן

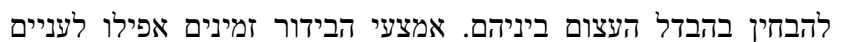

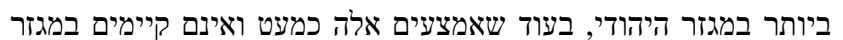

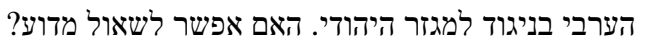
نلاحظفاء Original

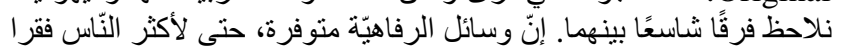

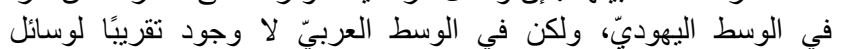
الرفاهيّة، وذللك خلافًا للوسط ولئ اليهوديّ. فهل لي بالسؤ ال لماذا؟

'When you visit Arab and Jewish towns and villages in Israel you see vast differences between them. Entertainment places are accessible even for the poorest members of Jewish society, while these resources hardly exist in the Arab sector, in contrast to the Jewish sector. May we ask why?'.

\subsection{Asked and Answered}

In the case of this rhetorical device, the speaker asks and immediately answers his own question. In contrast to other types of questions, this question does not seek information, it does not assert something like a rhetorical question, it does not contain the answer, and the audience is not expected to offer an opinion in response. The purpose of the question is to focus the reader's mind on what the speaker says next. In answering the question, the speaker can present his criticism and say what is on his mind 40 .

We find this strategy of asking a "real" question as opposed to a rhetorical question in theatrical texts, where it serves as a plot device. A "real" question obliges an answer

40 Landau, 1988, p. 164. 
and is considered a new element, not a repetition or paraphrase. The answer given connects the parts of the text thus moving the plot forward. This dramatic device is also found in political discourse41. This technique, which is used for convincing others, is similar to the rhetorical question, though not identical. In this case, the speaker employs a question and answer structure in order to rouse the listener to think more broadly about something the speaker assumes the listener has not previously considered:42

24. שאלה שתמיד עולה בדעתי: "במה אנו שונים מהיהודים?" אני בטוח אירו

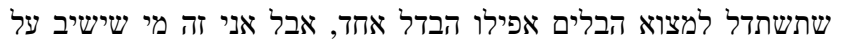

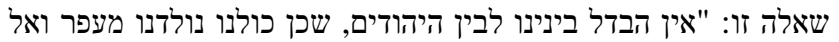

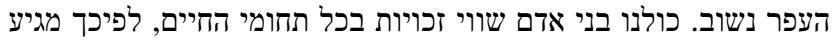
לנו מה שמגיע ליהודים". Original

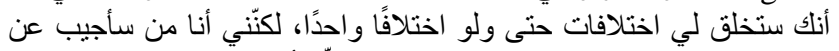

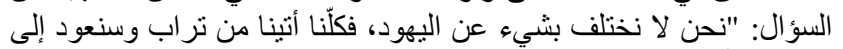

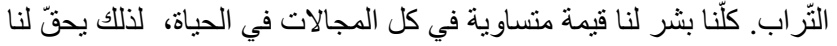

$$
\text { ما يحقّ لليهود". }
$$

'I keep wondering about the question: "How are we and the Jews different?" I am sure you will do your best to find differences, even one difference, but I am the one who's going to answer this question: "There is no difference between us and the Jews, because we all come from dust and we will all return to dust. We are all human beings with equal rights in all areas of life and so we deserve what the Jews deserve'.

25. אדוני השר, הצרכים הבסיסיים של המגזר הערבי אינם קיימים.

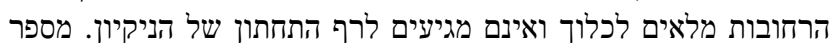

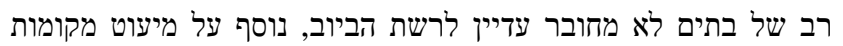

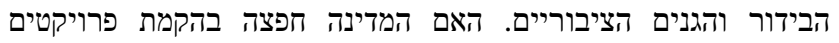

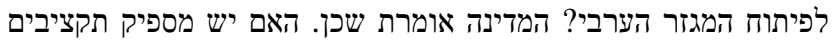

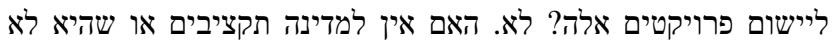

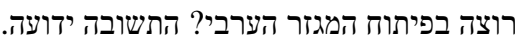
هوجأOriginal

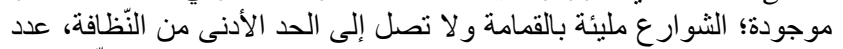

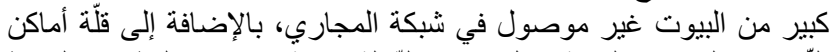

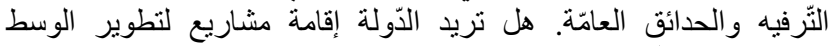

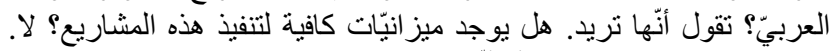

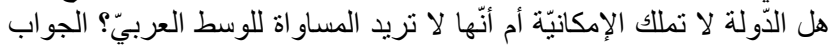
معروف.

'Dear Minister, The Arab sector's basic needs are not being met. The streets are filthy and fail to meet the lowest standards of cleanliness. Many houses are still not on the sewage system. There is also a lack of places of leisure and entertainment and very few public parks. Is the country interested in developing projects for the Arab sector? The state says yes. Is sufficient funding assigned for these projects? No. Is the country short of funds or is it not willing to develop the Arab sector? We know the answer'.

41 Even Zohar, 1970, p. 672.

42 Shaked, 2009. p. 141.

\subsection{Paradox}

A paradox is a statement consisting of two contradictory arguments. To resolve the paradox one argument must be sacrificed or a resolution found43. A paradox is valid or true if the two contradictory arguments are true. If one argument is false the paradox is false. If the two arguments are made at different times the paradox is false. It is false even if the arguments are true because the statements were made at different times 44 .

Justice means that if two situations are basically the same they should be treated the same way. Therefore, it is rational to treat two identical things the same and there is no reason or point in treating them differently. Here are a few examples of the paradoxes arising from the total disregard for justice:

26. אני תלמיזה בת 17 ומאז שנולדתי, רחובות הכפר שלי ללא שום פירום

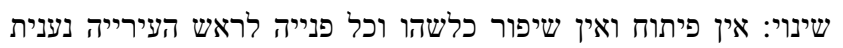

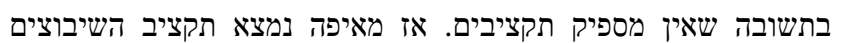

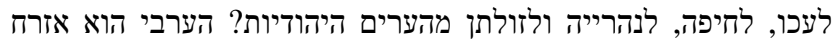

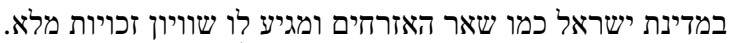
هriginal

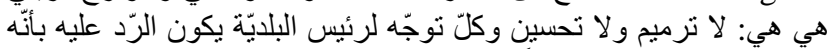

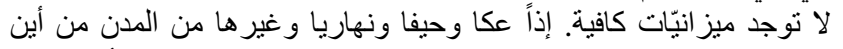

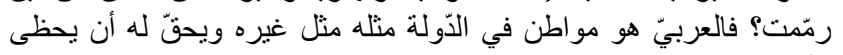
بالمساو اة.

'I am a 17-year-old student and all my life, the streets of my village are the same: no development, no improvement whatsoever, and if you ask the mayor the answer is always the same: no budget. So where do they find the money for repairs in Akko, Haifa, Nahariya, and the other Jewish towns. Arabs are Israeli citizens the same as any other citizen and they deserve full equal rights'.

The perpetual excuse that there is not enough money to pay for road works in the Arab sector is perceived as paradoxical. The claim that there is not enough money for the Arab sector when the Jewish infrastructure is being developed is seen as absurd.

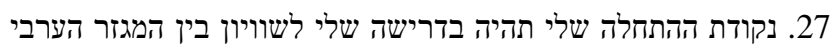

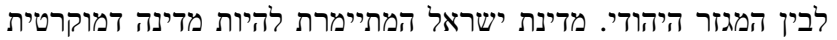

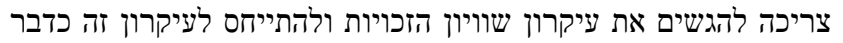

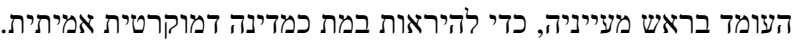
والقوب: Original

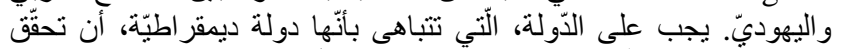

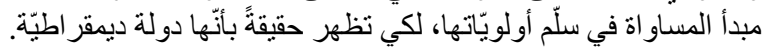

'I will open by asking for equality between Arabs and Jews. Israel pretends to be a democracy and to respect the principle of equal rights. But it needs to put this principle into practice and make it a priority so that it genuinely seems like a real democracy'.

Israel's claim to being a democracy that offers all its citizens equal rights clashes with its discriminatory behavior towards its Arab citizens and its failure to grant them full equal rights.

43 Perelman, 1994, p. 52; Tsur, 2004, p. 85

44 Landau, 1988, pp. 118-127; Darshan, 2000, p. 86. 
28. אני מבקש להציג בפניכם תמונות המשקפות את מצב החברה

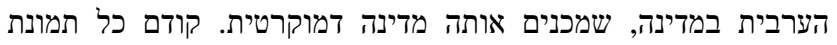

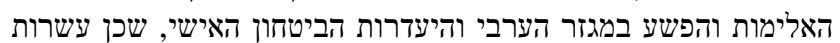

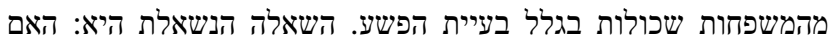

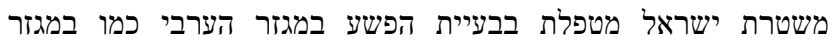

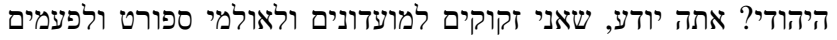

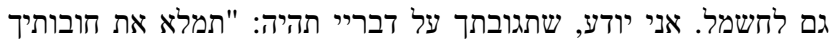

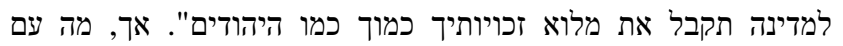

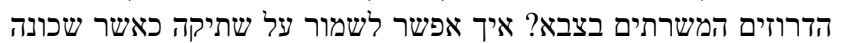

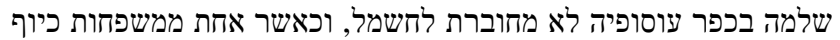

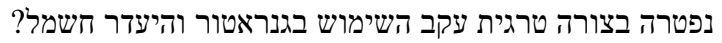
נ:Original

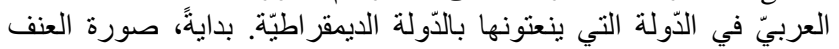

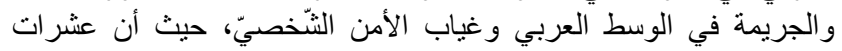

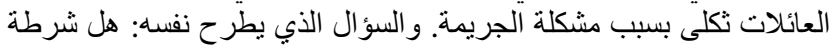

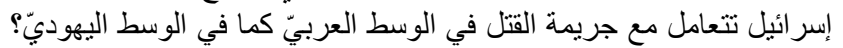

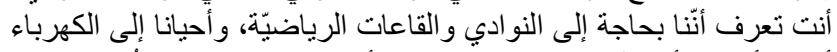

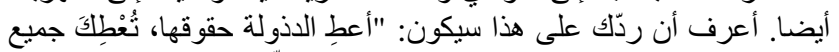

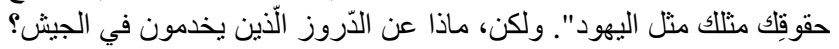

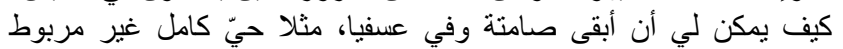

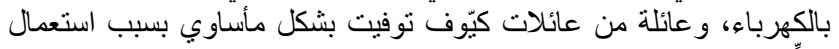

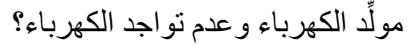

'I want to paint you a picture of the condition of Arab society in a country they call a democracy. The first picture consists of the violence and crime in the Arab sector, the lack of personal safety, and the tens of families who are bereaved as a result of the crime rate. The question: Is the Israeli police addressing the problem of crime in the Arab sector the same as does in the Jewish sector? You know we need clubs and sporting facilities and electricity as well sometimes! I know your answer: "Fulfill your obligations towards the state and you will get all your rights, just like the Jews." Yet, what about the Druse who serve in the army? How can we remain silent when a whole neighborhood in the village of Issufia is not on the electricity grid and a member of the Kayouf family tragically died when they used an electricity generator because there was no electricity?'.

29. לכבוד שר הפנים,

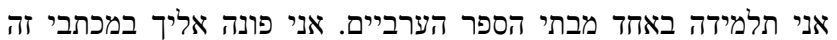

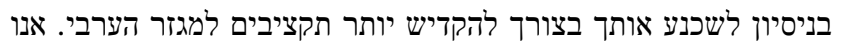

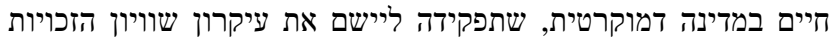

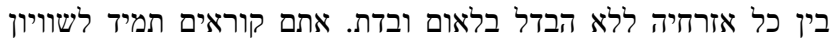

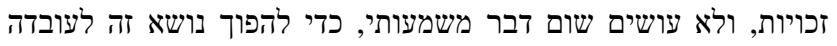

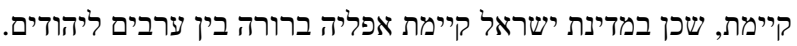
Original

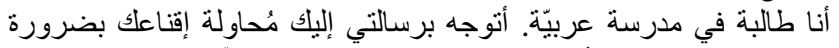

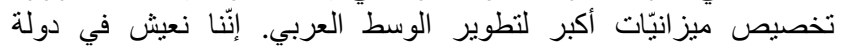

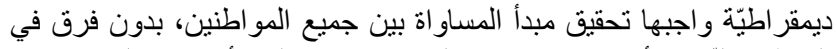

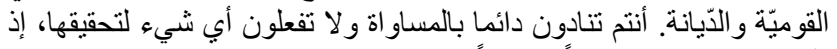

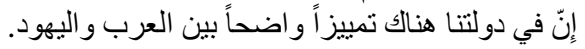

'Dear Minister, I am a student in an Arab school. I am writing to try to convince you that more funds are needed for the Arab sector. We live in a democratic country with a duty to ensure equal rights for all its citizens regardless of religion or race. You keep calling for equal rights, but you don't do anything significant to make this happen, and there is obvious discrimination in Israel between Arabs and Jews'.

Israel's protestations that it is a democratic state that grants equal rights to all its citizens is inconsistent with its discrimination against its Arab citizens and the failure to grant them full equal rights.

\subsection{Use of External Sources}

In order to convince their audiences, speakers may draw on the literary, religious, or folk sources associated with that audience's society or culture. These sources consist of poetry, sayings, proverbs, sacred writings, and myths.

According to Aristotle, these sources fall into two categories45:

A. Sources that are accepted and taken for granted, whose validity needs no proof. They include laws, contracts, and sacred writings. These sources are termed "arguments outside the art of speech".

B. Intellectual or emotional sources, such as sayings, proverbs, and myths which are quoted in order to prove things that are not obvious.

Myths nourish argumentation. According to Sivan's definition, myths are a form of political allegory, handed down in writing through the generations 46. A myth is structured as a dramatic story with heroes and villains and usually depicts an historical event. The mythical historical event is presented as larger than life; its heroes having the aura of epic heroes, despite being ordinary mortals. Myths speak to the emotions, carry the masses along, and leaving rationality behind. Their stories are handed down to subsequent generations, and form the basis of an organized belief whose believers have no need for logical persuasion 47 .

Sivan suggested that political myths have two functions48:

A. Interpretive function - Myths allow people to turn to the past for precedents and archetypes that will help them understand and interpret contemporary ideals. This involves drawing inferences from past events to present day issues.

B. Behavioral function-Myths rouse people to political action. For example: to defend a political or social order warranted by the myth.

Cassirer wrote regarding the interpretive function, that myths arise at times of crisis when human logic fails and people turn to the power of the mysterious49. Regarding the behavioral function, Cassirer argued that political myths drive political action.

These persuasion devices are divided into two groups according to Arabic linguistic rhetoric50: 1. 'qtibās - verses from the Qur'ān or Íadix; 2. ÓaÃmĐn- quotations from songs / poetry, prose, proverbs. According to Al-Íamwiy, the quotation which is used retains the same structure, order of words, and original meaning as the Qurān, though it might

45 Spiegel, 1993, p. 73.

46 Sivan, 1988, p. 9.

47 Sivan, 1988, pp. 9-11

48 Sivan, 1988 , p. 73 , pp. 78-79.

49 Cassirer, 1955, pp. 350-351.

50 Al -Zenad, 1922, p. 146; Darshan, 2000, p. 109. 
not retain the qur'ānic form, say, by adding a word or letter; deleting a word or letter; or changing the word order of a sentence. The original meaning of the qur'ānic quotation can also be altered to transmit a different teaching, the one the speaker wishes to transmit to his or her audience 51 . When a speaker uses quotations he or she relies on the reader's acquaintance with the cultural tradition underlying the quotation. If the reader is unfamiliar with the cultural tradition he will not understand it fully, and it will usually seem quite strange. As known, in Arab culture, the Qur'ān is regarded as the highest form of Arabic. Its style and language defy all efforts at imitation. Its absolute truth is made holy by seal of Allah, its verses are perceived as truths requiring no proof. It is easy to understand why speakers seek to harness these verses for their own ends and exploit their effect on the audience 52 .

Citing ancient sources returns the reader to the ancient historical situation. Readers now have to compare the text in the present with the original text they recall, thus enriching and deepening the present text. Thus, when people quote verses in their writing they are relying on the reader's familiarity with the cultural tradition which is cited. Readers who are unfamiliar with that tradition cannot grasp it fully.

According to Landau there are several reasons for quoting sources such as sacred writings53:

A. To reinforce the speaker's message by offering proof and support from the sources that his opinion or actions are justified; to disprove the opponent's position, and to criticize the opponent for an action linked to the quotation.

B. For purely stylistic reasons, to beautify the text-the speaker has a tendency to use these quotations when speaking and either consciously or unconsciously and sprinkles his speech with them. They have no persuasive rhetorical value.

C. Manipulation - the speaker quotes a verse out of context and interprets it symbolically so that it fits in with new ideas on contemporary issues. For example, Darshan 54 cites Bengo's ideas regarding the manipulative use of quotations from outside sources. Bengo recalled that Sadaam Hussain quoted verses from the Al-Anfal Surra in order to justify his genocidal campaign against the Kurds, which involved the use of chemical weapons, and was known as the Al-Anfal campaign55.

D. Archictectonic use - establish ideas by citing verses. Each new idea in a speech is preceded by a new verse. Another structure involves the use of several verses to present a single idea.

\subsubsection{Proverbs}

A proverb is a clear, concise statement of wisdom. It may be coined at any time, anywhere. The history of Arab folk sayings goes back farther than Islam, and, in the same way

51 Al-Íamwiy, 2001, pp. 442-443.

52 Darshan, 2000, p. 110.

53 Landau, 1988, pp. 182-185; Landau, 1993, pp. 50-51.

54 Darshan, 2000, p. 110.

55 Bengio, 1996. p. 246. that Arabic poetry was influenced by the desert, so were Arabic sayings, with their musical rhythm, comparisons, and internal rhymes. Islam saw the introduction of sayings with a religious and moral character, while, as noted, other sayings entered the culture from the geographical locality-the two types contributing to the ancient storehouse of sayings without displacing it. The Arabs carefully cultivated their sayings literature even publishing them in special books, mostly during the Umayyad dynasty, which was renowned for its nationalist Arab sentiments56.

Zelberstein noted that the role of sayings in discourse is to manipulate the audience and maneuver it into agreeing with the speaker's position. She identified two approaches to the use of sayings 57: the first is the pragmatic approach, which ascribes sayings with the power to influence or convince; speakers use them polemically; and the semantic approach, which conceives sayings as short sentences expressing wisdom, truth, or both. Zelberstein pointed out a circumstantial hypothetical connection between the two approaches, noting that speakers attribute truth or wisdom to sayings, since in most cases, audiences are influenced by them. 58

Spiegel defined sayings as an intellectual argument aimed at supporting a speaker's argument or disproving an opponent's claims-not by offering evidence and proof but by supporting the argument and creating the impression that it was substantiated59.

In this study, the students' writing used hardly any external sources. Only one letter quoted a saying:

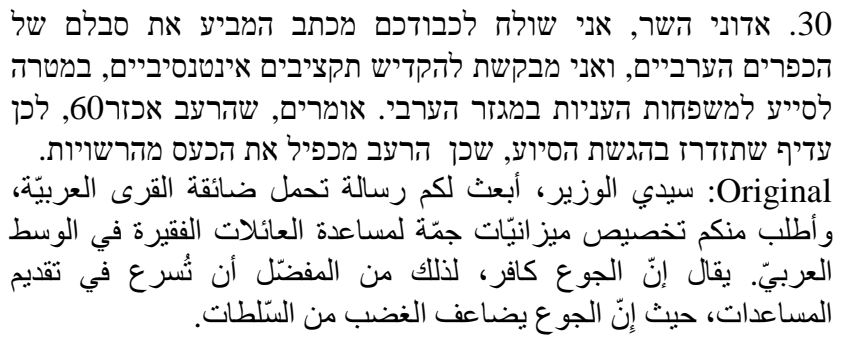

'Dear Minister, I am sending your honor a letter regarding the suffering of the poor families in the Arab sector and ask you will grant intensive funding to help them. They say that hunger is cruel61, so you had better hurry and provide aid since hunger doubles people's anger at the authorities'.

The saying is used to urge the minister to take urgent action to aid the poor Arab families.

\subsection{Antithesis}

Antithesis is a form of focalization constructed as a subordinate / secondary clause or "satellite" clause and a primary or "nucleus" clause, 62 which expresses opposing or

56 Dana, 2006. p. 6.

57 Zelberstein, 1990, p. 181-182.

58 Zelberstein, 1990, p. 193, 195.

59 Spiegel, 1993, p. 73, pp. 78-79.

60 Hunger has no mercy for the hungry.

61 Meaning that hunger has no mercy on the hungry and depresses their spirits.

62 The terms "satellite" and "nucleus" are terms from rhetorical structure theory (Mann, Matthiessen Christian \& Thompson, 1992, p. 42). 
contrasting ideas. The reader / audience feels positively towards the idea in the nucleus (the thesis in this case). Their understanding of the satellite, which rejects the opposite view to the nucleus, enhances the reader's positive attitude to the state of affairs described in the nucleus63:

31. אדוני השר, איננו אזרחים סוג ב, להפך אנו אזרחים מעל דרגה א:

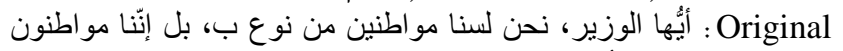

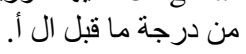

'Dear Minister, We are not second class citizens, quite the reverse, we are better than first class citizens'.

$$
\begin{aligned}
& \text { 32. מדינת ישראל לא מתייחסת לערבי כבן אדם, אלא כבובה, ששולטת }
\end{aligned}
$$

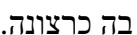

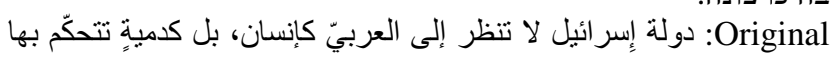

$$
\begin{aligned}
& \text { كما تريد. }
\end{aligned}
$$

'Israel does not treat Arabs like human beings but as toys that they can control'.

\section{Summary}

The popular rhetorical devices found in the students' writings were: paradoxes, analogical arguments, rhetorical questions, and repetition using synonyms and words from the same semantic field. The students used paradoxes to highlight the contrasting nature of Israel's declarations on the subject of full equal rights for all its citizens and its behavior and policies, which discriminate against its Arab citizens by not giving them full equal rights. The students regarded the paradox as a powerful rhetorical device which intensifies the message and convinces the addressee to accept and identify with their request.

Rhetorical questions formed one of the main rhetorical devices used in the students' writings. The students seemed to be aware of the rhetorical force inherent in rhetorical questions, especially when if they conclude a series of declarative sentences. Many students ended their discourse unit with a barrage of rhetorical questions. This strategy strengthened the emotiveness of the text while guiding the reader's consequent emotions in the direction sought by the writer, and made the reader feel things that would spur him or her to action, or at least, to accept the message.

The students' writings produced an impressive set of analogical arguments. Their arguments were based on the analogy that: if Arabs and Jews are Israeli citizens and Jews have a full set of rights then Arabs should also have a full set of rights, the same as the Jews.

The students' writings only rarely included external sources as a rhetorical device. They seemed to lack the knowledge needed to use outside sources such as verses from the Quran or Hadith, poetry or prose quotations in their writing.

Figures of speech such as metaphors, similes, personification, and hyperbole were hardly used. It seems

63 Mann \& Thompson, 1988, p. 283; Azar, 1999, p. 10; Thompson, Sandra \& Mann, 1987, pp. 359-381. that students felt that these devices lacked any special rhetorical force that could help them convey their message.

Students relatively rarely used the argumentative rhetorical device of asking and immediately answering a question. The answer to the stated question represents a new element, rather than a paraphrased repetition. The answer provided serves to link the textual elements and advance the speaker's efforts to talk the audience into accepting the message.

\section{References}

[1] Abadi, A. 1988. Discourse Syntax of Contemporary Hebrew. Jerusalem: Magnes. (in Hebrew)

[2] Abadi, A. 1998. Source Domains of Metaphors in Political Discourse in Israel. HELKAT LASHON 26: 56-67. (in Hebrew)

[3] Abdul latif, E. The strategies of convincing and influence in political discourse. Cairo: Egyptian General Book Authority. (in Arabic)

[4] Abu Khadra, F. 2009. The metaphor and the truth. Baqa ElGarbia: Al-Qasemi Arabic Language Academy. (in Arabic)

[5] Al-Íamwiy, I. 2001. Khizānat al-Adab wa Ġāyat al-Arab, I. Beirut: DAR SADER (in Arabic)

[6] Azar, M. 1992. Argumentative structures. In: Ben Shahar, R. \& Toury, G. (eds.). Hebrew - a Living Language, II. Tel Aviv: Publications of the Porter Institute for Poetics \& Semiotics, Tel Aviv University - Hakibbutz hameuchad: 9-23. (in Hebrew)

[7] Bengio, O. 1996. Saddam's Iraq. Tel Aviv: Tel Aviv University, Moshe Dayan Center for Middle Eastern and African Studies. (in Hebrew)

[8] Carpenter, R. H. \& Thompson, W. D. 1999. Choosing powerful words: eloquence that works. Boston: Allyn and Bacon.

[9] Cassirer, E. 1955. The Myth of the State. New York: Doubleday.

[10] Copi, I. M. \& Cohen, C. 1998. INTRODUCTION TO LOGIC. Prentice Hall: Upper Saddle River, NJ.

[11] Dana, J. 2006. Proverbs and Epigrams in Spoken Hebrew. Zefat: Zefat Academic College. (in Hebrew)

[12] Darshan, A. 2000. Rhetorical Characteristics of Speeches Given by Arab Leaders During the late 1990's. M.A dissertation. Ramat-Gan: Bar-Ilan University. (in Hebrew)

[13] Fruchtman, m. 1990. A Question of Style. Even Yehuda: Reches. (in Hebrew)

[14] Graber, D. 1993. Political communication: Scope, progress, promise. In: Finifter, A. W. (ed.). Political science: The state of discipline, II. Washington, DC:American Political Science Association: 305-332.

[15] Gitay, Y. 2005. The Rhetoric of Argumentative Reasoning: A Prolegomenon to the Art of Reasoning Between Religious and Secular Jews in Israel. University of Haifa: The Department of Communication. (in Hebrew) 
[16] Gitay, Y. 2009. Rhetoric: The art of coining a reality. In: Gitay, Y. (ed.). The Power of Words. Afula: The Max Stern Academic college of Emek Yezreel: 7-38. (in Hebrew)

[17] Gitay, Y. 2010. The Israeli Discourse: Rational versus Emotional Argumentation. Haifa: Pardes Publishing. 9in Hebrew)

[18] Gitay, Y. 2011. About rhetoric. Panim 56: 54-59.

[19] Gitay, Y. 2013 (a). THE ART OF RHETORIC. Moshav Ben Shemen: Modan Publishing House. (in Hebrew)

[20] Gitay, Y. 2013 (b). Returning to the Bible. Jerusalem: Rubin Mass. (in Hebrew)

[21] Israel, R. 2011. Introduction to Logic. Part 1. Raanana: The Open University of Israel. (in Hebrew)

[22] Lakoff, G. \& Johnson, M. 1980. Metaphors We Live By. London: The University of Chicago Press.

[23] Lakoff, G. 2002. Moral Politics: How Liberals and Conservatives Think. Chicago: University of Chicago Press.

[24] Landau, D. 1966. Notes on the Essence of the Literary Metaphor. $L \check{E} \check{S} O N E ́ N U$ 30: 305-320. (in Hebrew)

[25] Landau, R. 1986. Stylistic Rhetoric as a Means of Persuasion in Political Speeches. Hebrew Computational Linguistics 24: 43-68. (in Hebrew).

[26] Landau, R. 1988. The Rhetoric of Parliamentary Speeches in Israel. Tel-Aviv: Eked. (in Hebrew)

[27] Landau, R.1989. Syntactical-Rhetorical Repetition as Means of Persuasion in the Modern Political Address. In: Kaddari, M. Z. \& Sharvit, S. (eds.). Studies in the Hebrew Language and the Talmudic Literature. Ramat-Gan: Bar-Ilan University: 103-119. (in Hebrew)

[28] Landau, R. 1993. Citation as a Rhetorical Technique in Contemporary Rabbinical Speeches. AM VASEFER 8: 50-63. (in Hebrew)

[29] Livnat, Z. 2009. The Anatomy of Governmental Vagueness: A linguistic-historical look at political speech. In: Gitay, Y. (ed.). The Power of Words. Afula: The Max Stern Academic college of Emek Yezreel: 7-38. (in Hebrew)

[30] Livnat, Z. 2001. On implicit information and emotional manipulation. SCRIPT 2: 133-143. (in Hebrew)

[31] Mann, W. C. \& Thompson, S. A. 1988. Rhetorical Structure Theory: Toward a Functional Theory of Text Organization. Text 8: 243-281.

[32] Mann, W. C., Matthiessen Christian, M.I.M. \& Thompson, S. A. 1992. Rhetoric Structure Theory and Text Analysis. In: Mann, W.C. \& Thompson, S. A. (eds.). Discourse Description - Diverse Linguistic Analysis of a Fund-Raising Text. Amsterdam - Philadelphia: John Benjamins: 39-78.

[33] Mio, J. S. 1997. Metaphor and Politics. METAPHOR AND SYMBOL 12(2): 113-133.

[34] Muhammad, A. 2009. Arabic Rhetoric. Amman: Dar Al Massira. (in Arabic)

[35] Perelman, Ch. \& Olbrechts-Tyteca, L. 1969. The New Rhetoric. Notre Dame: Notre Dame University.

[36] Perelman, Ch. 1994. L'EMPIRE RHÉTORIQUE. Translated into Hebrew by Joseph Ur. Jerusalem: Magnes Press. (in Hebrew)

[37] Quirk, R. \& Greenbaum, S. 1989. A University grammar of English. England: Longman.

[38] Richards, I. A. 1965. The philosophy of rhetoric. New York: Oxford University Press.

[39] Searle, J. 2002. Consciousness and Language. Cambridge: Cambridge University Press.

[40] Shaked, Sh. 2009. Radiophonic argumentation. In: Gitay, Y. (ed.). The Power of Words. Afula: The Max Stern Academic college of Emek Yezreel: 130-150. (in Hebrew)

[41] Sivan, E. 1988. Arab Political Myths. Tel-Aviv: Am Oved. (in Hebrew)

[42] Spiegel, N. 1993. THE ART OF PERSUASION. Jerusalem: Magnes Press (in Hebrew)

[43] Thompson, S. A. \& Mann, W. C. 1987. Antithesis: A Study in Combining and Discourse Structure. In: Steele, R. \& Threadgold, T. (eds.). Language Topics: Essays in Honour of Michael Halliday, II. Amsterdam - Philadelphia: John Benjamins: 359-381.

[44] Thompson, S. A. 1996. Politics Without Metaphors is Like a Fish Without Water. In: Scott Mio, J. \& Katz, N. A. (eds.). Metaphor: Implications and Applications. New Jersey: Lawrence Erlbaum Associates: 185-201.

[45] Tsur, N. 2004. The Rhetoric of Israeli Leaders in Stress Situations. Tel Aviv: Hakibbutz Hameuchad. (in Hebrew)

[46] Tsur, N. 2011. Rhetoric found in op ed articles on the internet. Panim 56: 74-81. (in Hebrew)

[47] Weddle, P. 1978. Arguments - A Guide to Critical Thinking. New York: McGraw.

[48] Weinberg, B. 2006. Working on Words. Zefat: Hamodia. (in Hebrew)

[49] Zanned, L. A. 1992. Arabic Rhetoric: a course book. Lebanon: Arab Cultural Center Editions. (in Arabic)

[50] Zilberstein, D. 1990. The Proverb in Discourse. Hebrew Linguistics 28-30: 181-195. (in Hebrew)

\section{Biography}

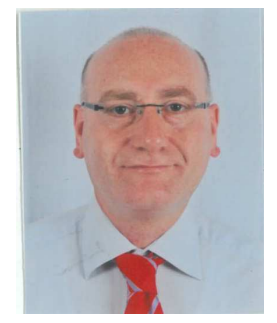

Adel Shakour holds a Ph.D. from the Department of Hebrew and Semitic Languages at Bar-Ilan University. $\mathrm{He}$ is a lecturer in the Department of Hebrew Language and Literature at Al-Qasemi Academy and An-Najah National University. $\mathrm{He}$ has done his post doctorate in the Department of Hebrew and Semitic Languages at the same institution for two years and currently is doing his post-doctorate in the Department of Hebrew and Comparative Literature at the University of Haifa.

His research interests include modern Hebrew, modern Arabic, contact linguistics, contrastive linguistics and rhetorics of political discourse. 